This PDF is a selection from an out-of-print volume from the National Bureau of Economic Research

Volume Title: Buying the Best: Cost Escalation in Elite Higher Education Volume Author/Editor: Charles T. Clotfelter

Volume Publisher: Princeton University Press

Volume ISBN: 0-691-02642-4

Volume URL: http://www.nber.org/books/clot96-1

Conference Date: $\mathrm{n} / \mathrm{a}$

Publication Date: January 1996

Chapter Title: Administrative Functions

Chapter Author: Charles T. Clotfelter

Chapter URL: http://www.nber.org/chapters/c11281

Chapter pages in book: (p. $162-178)$ 


\title{
Administrative Functions
}

\begin{abstract}
It is also very likely that some of the increases in real costs in higher education are ascribable to inefficiency, i.e., poor management. Education is extremely labor-intensive-nearly twice as labor-intensive as the average in private business. Research and development expenditures are tiny, compared to the private sector. 'Capital per worker' is abysmally low.

Henry Rosovsky, 1992'
\end{abstract}

THE NEXT THREE chapters examine some of the observable changes that have accompanied the expenditure trends noted in the previous chapters. Considering these changes should aid our understanding of the increases in spending, suggesting explanations and consequences for them. This chapter focuses on administration in the university, including the everyday office functions that are carried out in academic departments. The first section discusses administrative functions generally, and the second section examines data from some of the sample institutions on actual staffing patterns.

\section{THE TASKS AND TECHNOLOGY OF THE ADMINISTRATIVE SIDE}

Setting aside for the moment the university's central functions referred to in chapter 2-research, teaching, service, and patient care-what is left bears a close resemblance, and in some cases is virtually identical, to any number of other large business or government bureaucracies. Supporting activities include such functions as strategic planning, purchasing, maintenance, personnel, payroll, and accounting. In contrast to the latitude accorded to faculty members in their research, teaching, and service, the units that provide most of these support functions operate within a decidedly hierarchical organizational setting. The business of these units is, in a word, business.

Yet these functions have been cited as one of the culprits in the 
rising cost in universities. The president of the AAUP stated, "Undetected, unprotested, and unchecked, the excessive growth of administrative expenditures has done a lot of damage to life and learning on our campuses" (Bergmann 1991, p. 12). In particular, these administrative functions have been named in two indictments about cost escalation: (1) growth in number of functions, and (2) inefficiency of operation. Commentators have noted the efforts of colleges and universities to provide new services and "amenities," from manicured lawns, shuttle buses, and telephones in dorm rooms to glossy informational brochures, new recreation programs, and career counseling. ${ }^{2}$ Whatever one may think of the need for these features, it seems reasonable to view them as a direct result of the competition among colleges and universities to attract desirable students. ${ }^{3}$ Universities themselves frequently point to another example of increased administrative activity - the need to respond to a growing number of government regulations in such areas as occupational and environmental safety, grants and contracts, student records, and financial aid. ${ }^{4}$

A less sympathetic explanation for administrative growth in universities is a version of the age-old tendency for bureaucracies to grow. Analyzed by scores of social scientists and popularized by Parkinson (1957), this growth force has been identified in higher education most recently by Massy and Wilger (1992). They argue that the university's consensual approach to collective decisions, noted in chapter 2, and an increasing timidity in the face of hard decisions, have fed the demand for more administrators. ${ }^{5} \ln$ some publicized cases, high executive salaries and lavish items have aroused critics to denounce expenditures as excessive.

An alternative view is that much of the growth in administrative functions represents a rational substitution designed to economize on the use of faculty time. In the same way that nonfaculty employees may be taking on more of the advising function, administrators increasingly may be assuming some of the consensus-building functions traditionally held by faculty, leaving the latter more time for research. At the same time, the opposite case seems just as likely, namely, that the same forces pushing for more administrators also may have led to the growth of committees.

A second broad explanation for excessive cost in university administration is inefficiency, which corresponds to one of the three generic causes of high or rising costs noted in the introductory chapter. ${ }^{6}$ This explanation goes beyond the "cost disease" argument, which states that the lack of technological progress causes productivity to be stagnant, and that stagnant productivity, combined with 
rising real wages, increases real costs. As it is used here in the context of administrative work, inefficiency can be seen as waste. When managers do not use "best-practice" techniques to accomplish a job, or when workers are untrained or simply do not perform to their potential, less is accomplished per dollar of expenditure than could be accomplished under ideal circumstances. ${ }^{7}$ Rosovsky's (1992) criticism of the inadequate training and the "abysmally low" capital-labor ratio in universities speaks to this concern. So, too, do the current efforts in universities to apply management-improvement techniques in order to reduce staffs and improve service.

Yet, over the period covered by this study, the administrative workplace changed dramatically. Like the rest of the business world, universities were engulfed in a wave of new technology, most prominently in computing and communications. Consider what the office of 1976 did not have that, by the early 1990s, was taken for granted: touch-tone phones, voice mail, overnight package delivery, FAX machines, electronic mail, and, most important, personal computers. ${ }^{8}$ To suggest the growing importance of this type of equipment, Table 6.1 gives the total expenditures on computers and office machines for Duke's four sample academic departments and for a group of administrative units. ${ }^{9}$ Reflecting the overall growth in spending on computers discussed in chapter 4 , outlays for these units grew rapidly. The spending by the academic departments reflects the purchase of expensive minicomputers, used in research. Perhaps the

TABLE 6.1

Purchases of Computers and Other Office Machines, Selected Academic and Administrative Departments: Duke

\begin{tabular}{lrrr}
\hline & $1981 / 82$ & $1986 / 87$ & $1991 / 92$ \\
\hline $\begin{array}{l}\text { Expenditures on Office Machines, } \\
\text { Computers, and Software (Thou- }\end{array}$ & & & \\
$\quad$ sands of 1991/92 Constant Dollars) & & & \\
Four academic departments & $\$ 205$ & $\$ 654$ & $\$ 586$ \\
Selected administrative units & $\$ 27$ & $\$ 36$ & $\$ 56$ \\
Number Purchased by Four Academic & & & \\
$\quad$ Departments, Selected Equipment & 3 & 2 & 0 \\
Typewriters & 3 & 6 & 15 \\
Minicomputers (multi-user) & 7 & 32 & 51 \\
Personal computers & & & \\
\hline
\end{tabular}

Source: Data are from unpublished tabulations, Duke University.

aUniversity Counsel, Office of Research Support, Student Activities Office, Registrar, Accounting, General Services, Cost Accounting, and Sponsored Programs (component codes 10400, 11254, 11317, 11320, 13128, 13143, and 13180). 
most striking aspect of this table is the rapid increase in the number of personal computers, from 7 to $5 \mathrm{l}$, standing in contrast to the virtual disappearance of the typewriter.

As striking as these numbers are, the astounding aspect of this change is the increase in the power and capacity of the machines. Table 6.2 illustrates this improvement by presenting data on three computers actually purchased by one of Duke's academic departments during this period. Although the real prices for listed machines increased only modestly, all their important operational attributes improved dramatically. From the first to the third machine, the computational speed increased by a factor of 10 , memory (RAM) increased by a factor of 60 , and storage capacity increased by a factor of 500 . Surely, one would think, changes such as these must have had a large impact on the nature of costs in universities, as in business more generally. Studies of insurance and other service industries indicate that these innovations have indeed had an impact, but not necessarily what would have been predicted. The typical pattern appears to be that the initial impact of computers and other innovations is simply to increase costs." Although their introduction was accompanied by little or no reduction in staff, a shift in staff composition from clerical workers to professional workers occurred. Only after computers become a part of the business routine were service firms able to achieve significant restructuring of work routines or reductions in workforce."

In universities, computers were welcomed warmly. But rather

TABLE 6.2

Progress in Personal Computers: Three 1BM-Compatible Computers Purchased by a Duke Academic Department

\begin{tabular}{lccr}
\hline & \multicolumn{3}{c}{ Year Purchased } \\
\cline { 2 - 4 } & 1983 & 1986 & 1992 \\
\hline Machine & 1BM PC & IBM AT & Gateway 2000 \\
Price (1992 Dollars) & $\mathbf{3 , 8 5 4}$ & 5,535 & 4,129 \\
$\begin{array}{l}\text { Random Access Memo- } \\
\text { ry (in Thousands of }\end{array}$ & & & 8,000 \\
$\begin{array}{l}\text { Bytes) } \\
\text { Speed (MHz) }\end{array}$ & 128 & 512 & 50 \\
$\begin{array}{l}\text { Storage Capacity (in } \\
\quad \text { Thousands of Bytes) }\end{array}$ & 4.77 & 8 & 200,000 \\
\hline
\end{tabular}

Source: Data are from purchase orders, Plant Accounting Department, Duke University.

'Includes enhancements in the original purchase. 
than using them to save costs, the faculty, libraries, and administrative units that purchased them used these machines to increase output, for example, by increasing the number of statistical tests in research projects, reducing the time needed to retrieve information, or increasing the amount and complexity of the data that could be stored in administrative databases. ${ }^{12}$

\section{STAFFING PATTERNS}

With these advances in technology as backdrop, how did staffing patterns change during this period? A useful starting point in examining changes in staffing patterns is to consider the evidence on expenditures presented in the two previous chapters. Table 6.3 shows how the composition of compensation at Duke, Harvard, and Chicago changed over the periods for which detailed information was available for each institution. For Duke and Harvard, compensation for nonfaculty workers is divided among students (but does not count payments to graduate students for teaching and research assistance), administrative and professional staff, and nonexempt workers. The latter are workers who are subject to the provisions of the Fair Labor Standards Act, which requires supervised employees to be paid overtime. In each case, payments to faculty constituted the largest category of compensation but grew more slowly than did all compensation. By contrast, payments to administrative and professional staff at all three universities grew more rapidly than did all compensation and compensation for nonexempt employees. These patterns are consistent with an increase in the professionalization of the university workforce.

The aggregate evidence on employment in higher education also is consistent with this trend. Table 6.4 presents data on full-time staff in universities, based on reports to the Equal Employment Opportunity Commission (EEOC). The commission uses standardized job categories, which are briefly described and illustrated by specific jobs in Table 6.5. Over the 16-year period covered by Table 6.4, the number of full-time faculty grew at an average rate of 1 percent per year. By contrast, the number of administrators increased almost twice as fast, at a rate of 1.8 percent per year. However, the greatest growth was in the "other professionals" category-an average rate of 4.8 percent per year. These aggregate trends in growth and professionalization clearly are consistent with the models of bureaucratic growth noted in chapter 2 , although they also might be explained by an increase in the complexity of the functions performed. In order to obtain a better idea of the forces behind these changes in staff 
TABLE 6.3

Share and Growth of Payments to Labor, Arts and Sciences:

Duke, Harvard, and Chicago

\begin{tabular}{|c|c|c|c|c|c|}
\hline \multirow[b]{3}{*}{ Calegory of Labor } & \multicolumn{4}{|c|}{$\begin{array}{c}\text { Expenditures (In Thousands of } \\
1991 / 92 \text { Dollars) and Share }\end{array}$} & \multirow{3}{*}{$\begin{array}{l}\text { Growth } \\
\text { Rate }\end{array}$} \\
\hline & \multicolumn{2}{|c|}{ Beginning year } & \multicolumn{2}{|c|}{$1991 / 92$} & \\
\hline & Amount & Share & Amount & Share & \\
\hline \multicolumn{6}{|l|}{ Duke } \\
\hline Regular faculty & 22,474 & 40.0 & 34,435 & 38.4 & 5.3 \\
\hline Other faculty & 2,222 & 4.0 & 6,561 & 7.3 & 13.5 \\
\hline \multicolumn{6}{|l|}{ Administrative and } \\
\hline professional staff & 15,918 & 28.3 & 27,306 & 30.4 & 6.7 \\
\hline Nonexempt & 14,741 & 26.2 & 20,226 & 22.5 & 4.0 \\
\hline Students & 882 & 1.6 & 1,217 & 1.4 & 4.0 \\
\hline Total & 56,237 & 100.0 & 89,745 & 100.0 & 5.8 \\
\hline \multicolumn{6}{|l|}{ Harvard } \\
\hline Regular faculty & 39,889 & 41.8 & 59,070 & 37.4 & 3.9 \\
\hline Other faculty & 5,878 & 6.2 & 8,857 & 5.6 & 4.1 \\
\hline \multicolumn{6}{|l|}{ Administrative and } \\
\hline Nonexempt & 13,225 & 13.9 & 22,160 & 14.0 & $\begin{array}{l}9.1 \\
5.2\end{array}$ \\
\hline Students ${ }^{\mathrm{b}}$ & 19,330 & 20.3 & 25,554 & 16.2 & 2.8 \\
\hline Total & 95,372 & 100.0 & 157,826 & 100.0 & 5.0 \\
\hline \multicolumn{6}{|l|}{ Chicago } \\
\hline Regular faculty & 39,189 & 44.2 & 50,543 & 43.0 & 3.2 \\
\hline Other faculty & 3,228 & 3.6 & 8,096 & 6.9 & 11.5 \\
\hline \multicolumn{6}{|l|}{ Administrative and } \\
\hline professional staff & 22,450 & 25.3 & 33,076 & 28.2 & 4.8 \\
\hline Nonexempt ${ }^{c}$ & 23,831 & 26.9 & 25,737 & 21.9 & 1.0 \\
\hline Total & 88,698 & 100.0 & 117,452 & 100.0 & 3.5 \\
\hline
\end{tabular}

Source: Tables 4.1, 4.4, and 4.7.

Note: Figures for Duke and Chicago include prorated amounts from central administration and service components; Harvard compensation includes only Arts and Sciences.

'The beginning year was 1983/84 for Duke and Chicago and 1981/82 for Harvard.

'Includes exempt staff enrolled as students and payments to non-Harvard students.

Includes students.

composition, it is useful to take a closer look at staffs and the functions they perform.

\section{Approach}

Information on staffing in several specific academic and administrative areas in the sample institutions was studied in order to examine 
TABLE 6.4

Full-Time Employees of Higher Education Institutions, by Occupational Group, 1975 and 1991

\begin{tabular}{|c|c|c|c|c|}
\hline \multirow[b]{2}{*}{ Category } & \multicolumn{3}{|c|}{ Number of Full-Time Employees } & \multirow[b]{2}{*}{$\begin{array}{c}\text { Median } \\
\text { Salary, } \\
1991^{\circ}\end{array}$} \\
\hline & 1975 & 1991 & $\begin{array}{c}\text { Annual } \\
\text { Growth } \\
\text { Rate }\end{array}$ & \\
\hline \multicolumn{5}{|l|}{ Executive, Administrative, and } \\
\hline Managerial Employees & 102,465 & 136,908 & 1.8 & 47,319 \\
\hline Full-Time Faculty Members & 446,830 & 520,551 & 1.0 & 40,971 \\
\hline Other Professionals & 166,487 & 359,322 & 4.8 & 31,849 \\
\hline Secretarial, Clerical Employees & 302,216 & 365,332 & 1.2 & 19,140 \\
\hline \multicolumn{5}{|l|}{ Technical, Paraprofessional } \\
\hline Staff & 113,248 & 146,267 & 1.6 & 23,413 \\
\hline Skilled Crafts Workers & 51,370 & 62,052 & 1.2 & 25,502 \\
\hline \multicolumn{5}{|l|}{ Service, Maintenance } \\
\hline Personnel & 205,790 & 196,137 & -0.3 & 17,389 \\
\hline Total & $1,388,406$ & $1,786,569$ & 1.6 & - \\
\hline
\end{tabular}

Source: Data are from Kirshstein et al. (1990, p. 68) and unpublished tabulations produced by the Equal Employment Opportunity Commission (EEOC). In 1991, 3,285 institutions reported data to the EEOC.

${ }^{3}$ The faculty figure is the median for those with 9- to 10-month contracts, who constitute 70.5 percent of all full-time faculty.

staffing at the level of individual jobs. This level of detail made it advisable to limit the scope of the investigation, as examining an entire institution very likely would generate an overwhelming amount of detail, which would be virtually impossible to digest. The academic departments chosen were the same as those discussed in chapters 7 and 8. As explained there, three academic departments were chosen to represent different divisions of the arts and science enterprise: (1) natural sciences, (2) social sciences, and (3) humanities. At Duke, an engineering department was included as well because that university's arts and sciences included an engineering school. The departments differ not only by subject matter but also by research style, with the natural science department using laboratories and the humanities department using very little technical equipment other than word processors.

The choice of administrative areas is less simple. Virtually any area one chooses to examine is unlikely to be representative of overall patterns of change. For this reason, after consulting with several close students of universities, four areas were selected that either had been pointed to as examples of areas of growing administrative 


\section{TABLE 6.5}

Occupational Groups Based on EEOC Categories

\begin{tabular}{|c|c|}
\hline Group & Description and Examples \\
\hline $\begin{array}{l}\text { Executive, Administrative, and } \\
\text { Managerial Employees }\end{array}$ & $\begin{array}{l}\text { President, vice president, dean, di- } \\
\text { rector }\end{array}$ \\
\hline Full-Time Faculty Members & $\begin{array}{l}\text { Tenure-track faculty, adjunct in- } \\
\text { structors, emeritus professors } \\
\text { (except graduate student instruc- } \\
\text { tors) }\end{array}$ \\
\hline Other Professionals & $\begin{array}{l}\text { Support services usually requiring } \\
\text { college degree; research associate, } \\
\text { administrative assistant, career } \\
\text { counselor, psychiatric social worker }\end{array}$ \\
\hline Secretarial, Clerical Employees & $\begin{array}{l}\text { Secretary, receptionist, staff assis- } \\
\text { tant, clerk-typist, accounting clerk }\end{array}$ \\
\hline Technical, Paraprofessional Staff & $\begin{array}{l}\text { Positions requiring specialized } \\
\text { knowledge; computer programmer, } \\
\text { staff specialist, laboratory technician }\end{array}$ \\
\hline Skilled Craft Workers & $\begin{array}{l}\text { Positions requiring special manual } \\
\text { skills; laboratory mechanic }\end{array}$ \\
\hline Service, Maintenance Personnel & $\begin{array}{l}\text { Positions requiring limited, previ- } \\
\text { ously acquired skills; maintenance, } \\
\text { laboratory assistant }\end{array}$ \\
\hline Graduate Student Instructors & - \\
\hline Other Student Employment & - \\
\hline
\end{tabular}

responsibilities or were otherwise thought to represent pressure points in universities' attempts to deal with new functions or demands. Thus, the rates of growth of these areas should not be taken to be representative of administrative units in general. Overall growth rates for administration can be inferred from budget information expenditure data such as that presented in chapter 4 . What is of greater interest is the nature and composition of the staff changes that have taken place. In contrast to the academic departments, the sample administrative areas underwent varying degrees of reorganization over the period of study. In collecting this information, therefore, every effort was made to include all the administrative units conducting a given activity. Because the focus of this section is on administrative staffing, I made no effort to separate the portion of these units whose efforts related to arts and sciences activities from the portion related to professional schools, medical centers, or auxiliary enterprises, unless separate offices existed. The four administrative areas chosen were (1) university counsel, (2) 
sponsored research, (3) student services, and (4) personnel/human relations.

\section{University Counsel}

Theories of the increasingly litigious nature of society find a hospitable context in discussions of the growth in university administration, especially to the extent that they feature outside regulations as a cause of the growth of administrative staffs. Typically, at least part of the legal work of a university is performed by a separate office of university counsel, which acts as the university's in-house law firm. Outside law firms also may be hired to perform legal work. At Duke, a sizable portion of the activity of the counsel's office relates to the university's medical center. ${ }^{13}$

\section{Sponsored Research}

The term "sponsored research" refers to research that is funded, through grants and contracts, by government agencies, private foundations, or businesses. As this method of funding university research has grown in importance, so, too, has the administrative effort that universities expend to solicit and account for such support. The administrative effort with respect to sponsored research has three main functions: (1) helping faculty find out about and apply for funding, (2) accounting for the money spent, and (3) dealing with patents that might arise from such research. ${ }^{14}$ At both Duke and Harvard, the last 15 years has seen considerable change in the number, names, and organization of the offices carrying out these functions.

\section{Student Services}

Colleges and universities provide a raft of services to students outside the classroom, ranging from psychological and career counseling to special resources for minority students or foreign students to volunteer opportunities. The extent of these services appears to have grown during the last decade, with some commentators speculating that this trend demonstrates how institutions are becoming increasingly sensitive to consumer demand. The wide variety of services makes it necessary to draw some arbitrary lines. For the purpose of this analysis, 1 included all parts of student affairs offices dealing with student orientation, counseling, discipline, special programs for the disabled, minority students, and international stu- 
dents, and extracurricular programs. Where they are grouped together, religious and cultural organizations, academic advising, housing, dining, athletics, and student physical health were excluded..$^{15}$

\section{Personnel/Human Relations}

The traditional functions of personnel offices are to interview job applicants, train employees when necessary, and handle the paperwork associated with employee benefits and, sometimes, pay. This area, now commonly known as human resources, has witnessed considerable growth, which has been fueled by the variety of new employee benefits, attention to issues of fairness in hiring and supervision, and related government regulation. The functional areas covered by personnel are wage and salary administration (including job and pay classification), employee records, fringe benefit administration, training, labor relations, worker's compensation, and temporary employment. ${ }^{16}$ At Duke, the large medical center is the dominant force behind the size and growth in the human resources area. With a total workforce of some 21,000 in 1991, the university as a whole had twice as many employees as students; most of the employees worked in the medical center. At Chicago, the distinction between the medical center and the rest of the university was sharper, allowing the nonmedical portion to be identified separately.

The data available from the three universities to conduct an analysis of staffing trends differed markedly. Duke was the only sample university with computer-readable data from 1981 covering the number of workers by occupation. Harvard provided data on the number of FTE workers by unit, but without a detailed breakdown on occupational classification. At Chicago, the most that could be obtained was a listing of staff and short job titles taken from the university's telephone directory, which made either FTE calculations or classifications by occupation impossible; however, the period for which this information could be collected was longer than those for Duke and Harvard. In compiling the tabulations for each university, every effort was made to include all the relevant organizational units performing a set of functions over the time period. Nevertheless, because the importance of functions that had been performed outside these entities could have grown over time, the functions may have been consolidated into currently organized units, thus leading to the overstatement of the growth in these functions. Discussions with administrators who know the areas, however, suggested that this problem was not significant in the areas examined. 


\section{Trends at the Three Universities}

\section{Chicago}

Table 6.6 presents a summary of the data on staffing in the seven departments at the University of Chicago, excluding faculty, with the three academic departments combined. The totals are simply the number of staff listed in the university directory; no consistent data were available that would allow calculations of FTEs. With one ex-

TABLE 6.6

Staff Positions in Seven Units: Chicago, Selected Years

\begin{tabular}{|c|c|c|c|c|c|}
\hline Administrative Unit or Group & $1976 / 77$ & $1981 / 82$ & $1986 / 87$ & $1991 / 92$ & $\begin{array}{c}\text { Average } \\
\text { Growth Rate }\end{array}$ \\
\hline \multicolumn{6}{|l|}{ Three Academic Depart- } \\
\hline \multicolumn{6}{|l|}{ Human Resources } \\
\hline General & 6 & 6 & 7 & 7 & \\
\hline $\begin{array}{l}\text { Wage and salary adminis- } \\
\text { tration }\end{array}$ & 5 & 4 & 7 & 5 & \\
\hline Employment & 5 & 4 & 5 & 4 & \\
\hline Benefits ${ }^{a}$ & 2 & 1 & 5 & 9 & \\
\hline Employee/labor relations & 0 & 0 & 0 & 3 & \\
\hline Otherb & 1 & 1 & 2 & 2 & \\
\hline Total, excluding benefits & 17 & 15 & 21 & 21 & 1.4 \\
\hline Legal Counsel & 8 & 7 & 7 & 8 & 0.0 \\
\hline Sponsored Programs & 8 & 5 & 10 & 14 & 3.7 \\
\hline \multicolumn{6}{|l|}{ Student Services } \\
\hline Dean of Students & 7 & 8 & 10 & 10 & \\
\hline $\begin{array}{l}\text { Single student housing/ } \\
\text { house system }\end{array}$ & 2 & 3 & 4 & 4 & \\
\hline Career counseling and & & & & & \\
\hline placement & 5 & 6 & 8 & 6 & \\
\hline Student activities office & 3 & 4 & 4 & 12 & \\
\hline International affairs & 2 & 0 & 0 & 2 & \\
\hline Total & 19 & 21 & 26 & 34 & 3.9 \\
\hline
\end{tabular}

Source: Data are tabulations from University of Chicago Directory, various years.

Notes: Staff counts exclude faculty except those employed as full-time administrators. Functions directly supporting professional schools or the medical center were omitted.

aPart of function resided in payroll department before 1986/87.

'Includes training, human resources systems, workman's compensation, and employee records.

'Excludes the following offices that were part of Student Affairs at the University of Chicago: physical education, registrar, graduate affairs, admissions and financial aid, and residence halls and commons. 
ception, the activities covered in each row appear to be consistent over time and are not affected by reorganizations. The exception is the benefits area, part of which was transferred from payroll to human relations between the second and third years shown. The table shows that staff size in the academic departments and in the counsel's office did not grow, but that staff size in the other three areas did. In human resources, the total staff size, excluding benefits, increased from 17 to 21 , at an annual rate of 1.4 percent; because of that exclusion, this rate clearly is an understatement of total growth. Over the last five-year period, after benefits were fully included, the implied growth rate was 2.9 percent. In sponsored programs, growth through the period was uninterrupted, with an average annual rate of 3.7 percent. Student services also grew markedly, especially in the student activities office, confirming that the growth in this area noted by Rosovsky was not confined to Harvard. ${ }^{17}$

\section{Harvard and Duke}

Table 6.7 compares the staffing and growth for the three of the four administrative areas at Duke and Harvard covering the decade 1981 to 1991. Comparable data on student services at Harvard were unavailable. Employees are counted in terms of FTE workers. ${ }^{18}$ They are further divided according to whether they are exempt from overtime pay. Because exempt workers would tend to include most professional workers, it is possible to infer from these data whether the level of professionalization in the staffs carrying out these activities was increasing.

The figures suggest that the most rapid growth in staff size at both institutions occurred in the sponsored research area, with annual rates of 5.4 and 4.5 percent for Harvard and Duke, respectively, which is certainly consistent with the data obtained from Chicago. The only other clean comparison is in the counsel's office, where respective growth rates of 4.9 and 1.9 percent compare with no growth at Chicago. Because the practice of farming out significant legal work to outside firms is common, however, the increase in the number of staff may not be an especially accurate indicator of total activity. In this context, it is interesting to contrast the modest increase in staff in the counsel's office at Duke with the office's rapid rise in expenditures; over the period 1984 to 1992, its spending increased at a real rate of 8.1 percent. ${ }^{19}$ For a majority of cases shown in Table 6.7, exempt employment increased at faster rates than did nonexempt employment, suggesting an increase in the level of professionalization in the sample units. 
TABLE 6.7

Staff Size in Four Administrative Areas: Harvard and Duke, Selected Years (FTE Positions)

\begin{tabular}{|c|c|c|c|c|}
\hline & $1981 / 82$ & $1986 / 87$ & $1991 / 92$ & $\begin{array}{c}\text { Growth } \\
\text { Rate }\end{array}$ \\
\hline \multicolumn{5}{|c|}{ Sponsored Research } \\
\hline \multicolumn{5}{|l|}{ Harvard } \\
\hline Exempt & 17.0 & 20.6 & 33.0 & 6.6 \\
\hline Nonexempt & 27.3 & 25.6 & 42.7 & 4.5 \\
\hline Total & 44.3 & 46.2 & 75.7 & 5.4 \\
\hline \multicolumn{5}{|l|}{ Duke } \\
\hline Exempt & 10.0 & 16.8 & 20.8 & 7.3 \\
\hline Nonexempt & 16.4 & 12.4 & 20.4 & 2.2 \\
\hline Total & 26.4 & 29.2 & 41.2 & 4.5 \\
\hline \multicolumn{5}{|l|}{ Student Services } \\
\hline \multicolumn{5}{|l|}{ Duke } \\
\hline Exempt & 23.7 & 28.9 & 38.7 & 4.9 \\
\hline Nonexempt & 27.5 & 36.0 & 41.8 & 4.2 \\
\hline Total & 51.2 & 64.9 & 80.5 & 4.5 \\
\hline \multicolumn{5}{|l|}{ Legal Counsel } \\
\hline \multicolumn{5}{|l|}{ Harvard } \\
\hline Exempt & 8.0 & 11.0 & 11.0 & 3.2 \\
\hline Nonexempt & 3.0 & 5.0 & 7.0 & 8.5 \\
\hline Total & 11.0 & 16.0 & 18.0 & 4.9 \\
\hline \multicolumn{5}{|l|}{ Duke } \\
\hline Exempt & 7.0 & 9.0 & 8.0 & 1.3 \\
\hline Nonexempt & 5.6 & 6.6 & 7.3 & 2.7 \\
\hline Total & 12.6 & 15.6 & 15.3 & 1.9 \\
\hline
\end{tabular}

Source: Unpublished tabulations from Harvard: calculations based on unpublished data from Duke.

\section{Duke}

Considerably more-detailed information on the number and job tithes of employees allowed for the classification of employees according to occupation. Data on nonfaculty employees were obtained from payroll records for December in selected years (1981, 1986, and $199 \mathrm{l}$-years for which machine-readable information was available). The records include information on whether a person was on the payroll at any time during the calendar year and on the job type and level. Jobs were divided according to the EEOC classification scheme presented in Table 6.5. This classification has the virtue of distinguishing between faculty and administrators and makes it pos- 
sible to look for the hypothesized increase in professional employment. In contrast to the tabulations for Chicago, figures for the Duke academic departments include faculty.

Table 6.8 shows the composition of the staffs for the four academic departments added together. Overall, the FTE employment in these departments increased by 44 percent over the decade covered, for a 3.6 percent annual rate of growth. Not surprisingly, the category with the largest share of employment for these four academic departments is faculty, a category that includes non-regularrank instructors, such as lecturers, adjunct professors, and emeritus faculty. In contrast to the 1.0 percent rate of growth for faculty in all universities shown in Table 6.4, the number of faculty in these four

TABLE 6.8

Staff Composition in Four Academic Departments: Duke, Selected Years (FTE Positions)

\begin{tabular}{|c|c|c|c|c|}
\hline \multirow[b]{2}{*}{ Occupational Group } & \multicolumn{3}{|c|}{ Year } & \multirow{2}{*}{$\begin{array}{c}\text { Average Annua } \\
\text { Growth Rate, } \\
\text { 1981-1991 }\end{array}$} \\
\hline & 1981 & 1986 & 1991 & \\
\hline \multicolumn{5}{|l|}{ Executive, Administrative, and } \\
\hline Managerial Eniployees & 0.0 & 0.0 & 0.0 & - \\
\hline Full-Time Faculty Members & 104.3 & 114.4 & 131.3 & 2.3 \\
\hline Other Professionals & 30.0 & 54.0 & 47.7 & 4.6 \\
\hline $\begin{array}{l}\text { Clerical and Secretarial Employ- } \\
\text { ees }\end{array}$ & 29.4 & 28.2 & 30.0 & 2.0 \\
\hline Technical, Paraprofessional Staff & 11.8 & 22.6 & 15.7 & 2.9 \\
\hline Skilled Craft Workers & 0.0 & 0.0 & 1.0 & - \\
\hline Service, Maintenance Personnel & 0.0 & 0.0 & 0.5 & - \\
\hline Graduate Student Instructors & 16.1 & 19.2 & 29.6 & 6.1 \\
\hline Other Students & 21.4 & 37.9 & 50.4 & 8.6 \\
\hline Total & 213.0 & 276.3 & 306.2 & 3.6 \\
\hline \multicolumn{5}{|l|}{ Detail: Instructional Staff } \\
\hline Tenure-Track Faculty & 88.0 & 92.0 & 99.0 & 1.2 \\
\hline Nonregular Faculty & 16.3 & 22.4 & 32.3 & 6.8 \\
\hline Graduate Student Instructors & l6.I & 19.2 & 29.6 & 6.1 \\
\hline Total & 120.4 & 133.6 & 160.9 & 2.9 \\
\hline
\end{tabular}

Source: Data for tenure-track faculty are from the provost's office; for all other's, calculations using unpublished payroll data from Duke.

Note: For the purpose of this table, an employee's FTE value was defined as the product of (l) his or her normal work week as a proportion of 40 hours, and (2) the number of weeks worked per year as a proportion of 52 weeks.

accupational groups are defined in Table 6.5.

- No calculation could be made. 
departments grew at a 2.3 percent rate, corresponding to the more rapid growth in the arts and sciences faculty at Duke during this period. ${ }^{20}$ At the other extreme, there were no administrators (departmental chairs are counted as faculty), skilled crafts workers, or service/maintenance workers in these departments. University employees in the latter two groups normally would be assigned to service units. In light of the possible impact of computers on the university workplace, it is especially interesting that the growth in clerical and secretarial employment was the slowest of any group.

The section at the bottom of the table attempts to distinguish among types of instructors. From a separate source, slightly noncomparable information on the number of full-time faculty in the four departments is shown (the number of full-time not adjusted for leaves of absence or for administrative effort) with the excess of FTE total faculty being designated as nonregular faculty. To these lines are added the FTE totals for graduate student instructors and teaching assistants, whose duties might include grading and assisting during labs as well as teaching sections of larger courses. This breakdown shows that the number of tenure-track faculty in the four departments grew at only about one-sixth the rate for the two other categories of instructors. ${ }^{21}$

Table 6.9 gives similar information for the four administrative

TABLE 6.9

Staff Composition in Four Administrative Areas: Duke, Selected Years (FTE Positions)

\begin{tabular}{|c|c|c|c|c|}
\hline \multirow[b]{2}{*}{ Occupational Group } & \multicolumn{3}{|c|}{ Year } & \multirow{2}{*}{$\begin{array}{c}\text { Average Annual } \\
\text { Growth Rate, } \\
1981-1991\end{array}$} \\
\hline & 1981 & 1986 & 1991 & \\
\hline \multicolumn{5}{|l|}{ Executive, Administrative, and } \\
\hline Managerial Employees & 29.0 & 38.7 & 44.5 & 4.3 \\
\hline Full-Time Faculty Members & 1.0 & 2.3 & 2.8 & 10.3 \\
\hline Other Professionals & 49.4 & 74.3 & 88.0 & 5.8 \\
\hline \multicolumn{5}{|l|}{ Clerical and Secretarial } \\
\hline Employees & 57.1 & 72.1 & 88.2 & 4.3 \\
\hline Technical, Paraprofessional Staff & 6.1 & 9.2 & 14.0 & 8.3 \\
\hline Skilled Craft Workers & 0.0 & 1.0 & 0.0 & - \\
\hline Service, Maintenance Personnel & 0.0 & 0.0 & 0.0 & - \\
\hline Graduate Student Instructors & 0.0 & 0.0 & 0.0 & - \\
\hline Other Students & 12.1 & 19.7 & 18.5 & 4.2 \\
\hline Not Classified & 0.0 & 1.0 & 0.0 & - \\
\hline Total & 154.7 & 218.4 & 256.1 & 5.0 \\
\hline
\end{tabular}

Source: Calculations using unpublished payroll data from Duke.

- No calculation could be made. 
areas. The overall rate of growth in these areas, 5.0 percent per year, is more than that for the academic departments, but this comparison may mean very little because the number of units covered was small, and they probably are not representative of the entire administrative enterprise. In these units, the most rapid rate of growth (ignoring the faculty category, which has a very small base) was in the technical and paraprofessional group, followed by the "other professional" group. Secretarial, administrative/managerial, and student workers all increased at below-average rates. Among the two largest groups of workers in these administrative units, the "other professional" category appears to have grown relative to clerical and secretarial workers, a trend that seems consonant with the rising importance of computers.

\section{CONCLUSION}

In order to accomplish the mission that sets them apart from other firms and nonprofit organizations, colleges and universities perform certain service and administrative functions that are quite similar to what is done in the service sector of the corporate world. Three sets of factors affect how the scale, organization, and technological virtuosity with which these functions are performed in universities. The first factor is the demand from the customers of universities, most notably, students and government agencies. In their efforts to compete for students, institutions sought to provide new services; this attempt seems especially evident in the area of student services. Colleges and universities also are under pressure from regulatory agencies, which probably has led to some increases in staff size in such areas as cost accounting and sponsored programs.

A second set of influences, coming also from the outside, was the dramatic transformation in the technology of the workplace, epitomized by the gradual appearance over the period of study of a personal computer on a desk in almost every office. During the 15 years covered by this analysis, perhaps the most important effect of this technological transformation was to require a more highly trained workforce in university administrative positions-an effect that had a profound impact on the economy at large. Rather than reducing the workforce, computers appear to have forced it to become more professionalized. By the early $1990 \mathrm{~s}$, therefore, computers had not saved universities very much money. They niay well have increased productivity, especially in research, but this improvement produced little in the way of cost savings.

The third set of forces affecting the size and operation of adminis- 
trative staffs in universities are internal, comprising both the "administrative entrepreneurism" noted by observers Massy and Wilger (1992) and efforts intended to lean in the other direction, toward smaller staffs. Perhaps taking a cue from the corporate world, many universities undertook serious efforts in the 1990 s to reduce nonfaculty staff or to increase the quality of service provision, or both, as evidenced by prominent campaigns for "quality improvement" and "process re-engineering." If the experience of firms in service industries is any predictor, the failure of computers and other innovations to bring about reductions in staffing does not necessarily preclude the possibility that such reductions eventually will occur. 